УДК 929:001-043.86:378.4(477.74-21)

DOI: https://doi.org/10.18524/2707-3335.2020.1(23).202091

\author{
Murashko Elena, \\ Head of the Information and Bibliographic Department \\ 24 Preobrazhenskaya St., Odessa, 65082, Ukraine \\ tel.: (048) 7221210 \\ e-mail: bibik@onu.edu.ua \\ Samodurova Vera, \\ Chief Bibliographer \\ Scientific Library of the \\ Odessa I. I. Mechnikov National University \\ 24 Preobrazhenskaya St., Odessa, 65082, Ukraine \\ tel.: (048) 7221210 \\ e-mail: bibik@onu.edu.ua
}

Scientific Library of the Odessa I. I. Mechnikov National University

\title{
THE DEVELOPMENT OF SCIENCE AT THE ODESSA I. I. MECHNIKOV NATIONAL UNIVERSITY THROUGH THE LENS OF BIOGRAPHY
}

\begin{abstract}
This article reveals the role of personality in the history of a classical university, development of domestic biography as a whole, as well as in Odessa I. I. Mechnikov National University, in particular at the university Scientific Library. The publication briefly analyzes the developments in the sphere of domestic biography. Scientific library of Odessa I. I. Mechnikov National University for many years practices, relying in their activities on recommendations and examples drawn from theory and methodology of science «biography», has accumulated rich experience in implementing biographical research, making them one of the priority areas in its work. The article lists the main works of the university library in this recent years: publications in scientific journals and collections, written in the form of biographical studies; encyclopedic dictionaries and reference books; personal bio-bibliographic indexes and monographs. Attention is emphasized on the publications of the series «Development of Science at Odessa I. I. Mechnikov National University», founded in 2010. The series is published under close academic collaboration of the library with departments of the university.
\end{abstract}

Keywords: Odessa I. I. Mechnikov National University, development of science, biography, M. M. Lange, M. Ya. Grot, V. I. Grigorovich, Faculty of Physics, Faculty of Geology and Geography, Department of Ukrainian Literature.

University does not symbolize only studying, teaching, research and educational work, first of all University means a community of personalities, that is professors, scientists and students. It is through the prism of their achievements, actions, characters that the face of a certain educational institution, its image is created. 
In this context, the scientific discipline «biography studies» and the concept of «scientific biography» or «intellectual biography», etc. can be regarded as appropriate. These concepts are considered in detail by a leading researcher in the Institute of Biographical Research of the Vernadsky National Library of Ukraine (NBUV) Cand. Sc. (History) S. N. Lyashko [10]. In particular, she emphasizes that «historical and biographical researches occupy a prominent place in the history of science making it possible to personify the history of its branches, assess the contribution of scholars, individuals involved in research and organization of science» [10, p. 25]. Another specialist L. D. Berezovskaya, Dr. Sc. (Pedagogy), Professor Corresponding Member of the National Academy of pedagogical sciences, notes that

nowadays biographical information has become a leading component of socially significant information, its dissemination being an important part of ensuring intellectual and mental self-reliance and information security of Ukraine [1, p. 298].

V. I. Popyk, Dr. Sc (History), Corresponding Member of the National Academy of Sciences of Ukraine (NANU), Director of the Institute of Biographical Research of the NBUV (since 2003), General Director of NBUV (2013-2018), emphasized on the formation of biography studies as a separate academic discipline in his report at the 5th International Scientific Conference Library. Science. Communication. Strategic objectives of the development of scientific libraries (Kyiv, October 3-5, 2017):

Ukrainian biography studies during the years of independence came out of a difficult situation of ideological oppression, having gone through several very difficult and painful stages of revival. The relentless growth of readers 'interest in biography proves its great role in the elevation of the intellectual and spiritual interests of our compatriots, in the development of «humanity capital» of Ukrainians. The undisputed conquest of the years of independence is the formation of biography studies as an independent, full-blooded academic discipline [9, p. 326-327].

The purpose of the article is to outline the development of the national biography studies from its origins to the search for innovative ways to create texts-biographies. The article also aims at highlighting the advances of the Scientific Library of the Odessa I. I. Mechnikov National University in the field of biographical research resulting in publications of various types, in particular those of the series under general title Scientific Development at Odessa I. I. Mechnikov National University.

The origins of Ukrainian academic biography studies date back to the $19^{\text {th }}$ century, when V. Antonovich with a group of scientists (M. Hrushevsky, V. Shcherbyna, S. Efremov etc.) made an attempt to create a biographical dictionary [2, p. 360; 5, p. 147-148].

The idea of creating such a dictionary can be later found in the Statute of the Ukrainian Academy of Sciences (November 26, 1918) the academy being in charge of Permanent commission for compiling a dictionary of Ukrainian eminent persons of science, history, art and social movements [7, p. 169] (the commission was created with the participation of V. I. Vernadsky as the first president of the Ukrainian Academy of Sciences [10, p. 27]). V. I. Vernadsky believed that science was born by practical human activities, developing as its theoretical reflection and generalization [11, p. 30]. 
A monograph Biographical tradition and scientific biography in the history and modernity of Ukraine by V. S. Chishko, a founder of modern methodological principles of Ukrainian biography studies, an initiator of the creation and the first director of the Institute of Biographical Research of the NBUV, President of the Ukrainian Biographical Society, can be considered as a significant contribution to the development of biography studies. The author emphasizes that «the object of biography as an academic discipline is a person, a figure of history as a phenomenon in his/her various relationships with society» [15].

Thus, the biography of a scholar, on the one hand should be considered as information about personality, and on the other as knowledge about the progress of a particular science and vice versa. The mechanism of interaction of an individual with an intellectual community, intellectual with his entourage, according to I. I. Kolesnik, is advisable to consider through the prism of his/her scientific career [cited. after Popova, s. 33]. The conclusion made by V. V. Vashchenko having studied studying and summarized the works of foreign researchers seems reasonable:

Instead of «biography-hagiography» «biography-contextualization» has become relevant, which emphasizes the existence of various contexts - intellectual, political, ideological, which determine the external contours of the life of the scientist [3, p. 477-478].

A new «discourse of biographical consciousness», the search for innovative ways of creation of biographical texts, a different vision of biohistoriography are inevitable in a new cultural and historical epoch, which formulates the «eternal questions» of comprehension of the individual in the «new mental material», using another categorical apparatus [16, c. 132]. That is how Prof. T. N. Popova, CandSc (History), representative of scholars from Odessa I. I. Mechnikov University engaged in biography studies. summarizes the research of scientists as well as her own vision of the problem. She proposed her variant of the biohistoriographic model, which provides for biohistoriographic analysis and outlines the scope of meaningful positions as components of «a biography» [16, c. 43-49].

In the course of durable activities based on theoretic recommendations theory and methods of biography studies, the Scientific Library of Mechnikov University has accumulated extensive experience of the implementation of biographical research, making them one of the priority areas their work.

The results of scientific activities in this field are presented by numerous publications in scientific journals and collections, encyclopedic and biographical dictionaries, biobibliographic references and even monographs, such as a biographical dictionary Professors of Odessa (Novorossiysk) University ( $1^{\text {st }}$ edition in 2000, $2^{\text {nd }}$ edition in 2005), an encyclopedic dictionary Graduates of Odessa (Novorossiysk) University (2005, $1^{\text {st }}$ issue; 2010, $2^{\text {nd }}$ issue); informational publications Employees of Odessa I. I. Mechnikov National University as awardees of state awards of Ukraine (2010) and Let us not forget, let us remember: the staff of the Odessa I. I. Mechnikov National University in the Second World War (2015); a reference book Golden Names of Odessa Mechnikov National University (1865-2015) (2016). The Scientific Library has launched a series of biobibliographic references «Biobibliography of University Scientists», in its frames both separate issues and papers dedicated to one person. 
Thanks to these publications, not only the life and academic activities of scientists but also the formation and functioning of an educational institution, the progress of science, etc. can be traced. In the context of this article, a series Development of Science at the Odessa I. I. Mechnikov National University, which was launched in 2010 on the occasion of the $145^{\text {th }}$ anniversary of the University, deserves special attention.

The series is being prepared in close academic cooperation of the library with University departments. The results of the integration of the staff of the Scientific Library for the implementation of scientific work with departments of ONU are so-called hybrid research projects under general management of the editorial board headed by the rector of the University, Dr. Sc (Political sciences), Prof. I. N. Koval [17, p. 158-159]. Six monographs were published in the frames of the series: three of them dedicated to personalities (N. N. Lange, V. I. Grigorovich, N. Ya. Grot) and three - to the academic teams (Physics and Geology and Geography faculties, department of Ukrainian literature of the Philological faculty).

In the mentioned biographical works, the authors tried to create images of scholars of different specialties, in a certain context, using different composition variants of biographical material and applying a specific biographical key. Each specific biography describes the environment in which the person lived and worked within the university corporation. Working on the publications involved a large amount of factual material collected in the archives of the University, city and region. Each of the editions of this series has its own concept and structure, which was worked out taking into account the fields of activity and the specifics of the views of a scientist or a team of researchers, reflecting their worthy contribution to science at the University of Odessa. Monographs published in the series Development of Science at Odessa I. I. Mechnikov National University prepared by different authors differ in structure, have different volume, and devoted to different topics etc., but they also have common features being based on biographical research and including a biobibliographic reference as one of the parts in its content.

Biobibliographic reference boos remain relevant publications, but currently the Scientific Library is looking for new incarnations of this type of publications. It is in the publications of the series Development of Science at Odessa I. I. Mechnikov National University biobibliographic references appear in a modernized form, with in-depth information, with expanded and improved research and reference and search instruments. Within a series reference book can be regarded as an integral part of monographs. Library staff are not limited to the functions of compilers of references, they are the authors of one or several parts of the text.

In general, the monographs of this series are comprehensive. First, it is a collective study that involves the interaction of members of the author team. Secondly, parts of the monograph include not only the textual results of the study, but also a biobibliographic reference, and previously unpublished materials, and so on. Third, the author team often incorporates representatives of various branches of science, so the portrait of the researched scholar becomes multifaceted. And, lastly, it is this multifaceted approach that provides an expanded view of the progress of a particular science. 


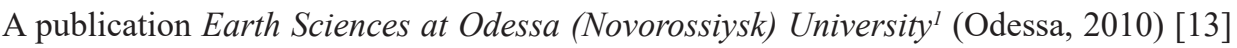
was realized on the occasion of the anniversary of the University. An issue "Geographical and Geological Sciences" opened this series having its own structure and presenting elements of biography studies. The monograph highlights the main milestones in the history of creation and development of the Faculty of Geology and Geography, in particular separate departments. The publication focuses on the founders, deans, heads of departments as well as of scientific departments. Lists of main publications of the staff are added to the chapters on separate departments. The text considers the directions of academic activities in the field of geological and geographical sciences at the University.

The contribution of physicists of Odessa (Novorossiysky) University in the development of science in Odessa, 1920-19302 (Odessa, 2010) [4] is next edition of the series Development of Science at the Odessa I. I. Mechnikov National University. Publications on the history of the University and its departments covered the formation of physical science at Novorossiysky University and its further development at Odessa University, which was restored in 1933. During the reorganization of higher education in Ukraine in 1920-1933, a number of institutes, technical schools and research institutions were established on the basis of University temporary closed in Odessa. The history of the Faculty of Physics and the contribution of Odessa scholars in the development of physical science in this difficult period needed further study. The research was based on extensive factual material, archival documents and memoirs of the participants. Historical events and the activities of scientific institutions and Universities during the reforms of the 1920s and 1930s are presented through biographies of professors, staff and graduates of the Faculty of Physics and Mathematics of Novorossiysky University. The ideological context of a «scientific biography» determines the affiliation of individuals to a specific professional community [10, p. 29], represented in this case by physicists.

Subsequent publications cover the scientific achievements and life path of a particular person helping trace the history of the university. These are properly biographical studies emphasizing on the contribution of each scientist to progress of science. The publications have an original concept, i. e. built on their own structure, which takes into account the directions of scientific activity, the specifics of the views of the scientist. Such are monographs Scientific heritage of N. N. Lange in the University Library (2010) [14], Seeker of Slavic treasures V. I. Grigorovich (2015) [6], On the eve of the apogee: the Odessa years of the philosopher and psychologist Professor Nikolai Yakovlevich Grot (2016) [12].

The monograph, dedicated to the outstanding scientist, the founder of domestic experimental psychology N. N. Lange, was published within the series «Psychology» and was the result of joint work of the Scientific Library and the Department of Social psychology of Odessa I. I. Mechnikov National University ${ }^{3}$. The impetus for this publication was Professor Lange's archive conserved in the University Library. The scientist's archive was acquired in 1965 and immediately became an object of systematization and cataloguing.

\footnotetext{
Authors: Ye. A. Cherkez, Ya. M. Bilanchin, Ye. N. Krasekha, Ye. P. Larchenkov, A. G. Topchiev, Yu. D. Shuyskiy. 2 Authors: M. A. Podrezova, V. V. Samodurova, Ye. S. Murashko.

3 Authors: V. I. Podshivalkina (section 1), R. N. Svinarenko (section 1), Ye. V. Polevshchikova (section 2) ; compilers: M. V. Alekse€nko, Ye. V. Berezhok, O. L. Lyashenko, I. V. Pigulevskaya, Ye. V. Polevshchikova, Ye. V. Saveleva (section 2, Applications); V. S. Kochmar (section 3: Bibliographic index).
} 
N. N. Lange's heritage had been studied by the staff of the University library for years. In 2008-2009, the archive was recatalogued consisting nowadays of 1238 documents in 13450 folios. These are handwritten documents, typewritten and published materials, newspaper clippings, photographs that can be divided into three main sections: biographical documents; N. N. Lange's creative work; manuscripts and printed materials of other authors. More detailed information on the origin, the contents of the archive and its acquisition by the University Library is presented in the second section of the monograph [14, p. 31-39]. Archival documents on the history of the cabinet of experimental psychology at the Faculty of History and Philology of Novorossiysky University, publications of N. N. Lange's works, which have not lost their relevance, as well as articles by one of the students of the scientist a teacher and psychologist M. I. Gordievsky are the materials of great interest for modern researchers. An integral part of the monograph is a biobibliography reference, where basic information about N. N. Lange's scientific, pedagogical and social activities is systematized and generalized. The reference consists of three parts: a chronological index of the scientist's works, literature about him and reference and auxiliary apparatus, consisting of an index of personal names and an alphabetical list of printed works.

Issue «Slavic Studies», dedicated to the famous scientist, one of the founders of domestic Slavic studies, the first dean of the Faculty of History and Philology Novorossiysk University V. I. Grigorovich ${ }^{4}$, is a result of collaboration of library specialists (M. V. Alekseenko) and historians (Prof.O. B. Dyomin). The first section highlights the main stages of V. I. Grigorovich's life and career. Particular attention is paid to the scientific, pedagogical and administrative work of the famous Slavist in the Imperial Novorossiysky University in 1865-1876. The second section of the publication is devoted to the formation of a unique book collection of V. I. Grigorovich, which was collected for educational and scientific goals mostly in 1844-1847 during his scientific journey in Slavic lands and is now stored in the stacks of the Scientific Library of the University. The gift of the Slavic scholar Viktor Ivanovich Grigorovich (1864-1865) became the first personal book collection in the stacks of the University library stored as «Department of Slavic Philology of Professor V. I. Grigorovich» [6, p. 54]. The formation of a book collection on the history, philology and literature of the Slavs is closely intertwined with the presentation of the biography of the scientist, his academic preferences, reasons and results of the trip, the subject of activity and research of the scientist. The publication describes in detail the book collection from the point of view of the linguistic affiliation of the publications, considers the ownership features, paying attention to valuable and rare editions. The third section contains a catalogue of Grigorovich's book collection.

Bibliographers, historians, philosophers and psychologists have joined forces to work on the next edition of the series (Psychology. Philosophy). It is dedicated to the outstanding philosopher and psychologist Professor N. Ya. Grot, who made great efforts to form the national philosophical and psychological discourse and philosophical and psychological

\footnotetext{
Authors: O. B. Domin (section 1), M. V. Alekseenko (section 2); compiler M. V. Alekseenko (section 3: Katalog knizhnogo sobraniya); author of preface I. N. Koval.

5 Authors: V. M. Khmarskiy (part 1, section 1), O. Ye. Muzychko (part 1, section 1), M. A. Podrezova (part 1, section 2), I. V. Golubovich (part 1, section 3), V. I. Podshivalkina (part 1, section 4); compilers: V. V. Samodurova, Ye. S. Murashko (part 3: Bibliographic index)
} 
activities. This work turned into a multifaceted project, aimed at making an in-depth analysis of the historical context of the activities of University professors. The coverage of events and the atmosphere in which he worked, the study of his environment, the social activities of the scientist made it possible to understand the multidimensional historical context of the Odessa period of N. Ya. Grot's creativity [12, p. 14]. It is through the various vectors of N. Grot's work that both his personal scientific achievements and progress of psychological and philosophical science are highlighted, as well as the role of personality in the history of the University. Such a multifaceted analysis was made for the first time within the series of publications Development of Science in the Odessa Mechnikov National University. An integral part of the publication is a biobibliographic reference of the academic heritage of the scholar compiled on the basis of stacks of scientific libraries of Odessa I. I. Mechnikov National University, Kharkiv V. N. Karazin National University and library of Nizhyn N. Gogol State University. The monograph contains abstracts of N. Ya. Grot's lectures on the philosophy as well as little-known articles published in Odessa newspapers of the time.

In 2018, a two-volume monograph was published within the series (Philology), which resulted from a joint long-term project of the Scientific Library and the Faculty of Philology. The book consists of a biobibliographic reference and an anthology of literary critical essays of the Department of Ukrainian Literature ${ }^{6}$ [8]. In terms of volume, structure, form of presentation, scale of information coverage this is the first publication in Ukraine of this kind. Its authors aimed to study the prerequisites for the emergence, formation and development of the Department of Ukrainian Literature of Odessa University through the prism of academic achievements of its representatives and the main fields of research of the spectrum of scientific disciplines [8, p. 7]. The creation of one of the oldest Ukrainian studies departments of classical universities in the South of Ukraine opened a complex and glorious path of development of domestic literary and critical thought. Representatives and students of the Odessa literary school aware of their creative vocation in various fields of philology not only in the Odessa region, are well- known outside of Ukraine, constituting its intellectual capital. The first volume contains an article on the history of the department, accompanied by illustrative material, and a biobibliographic index of works by 47 personalities of the department. Biographical information provided about each scientist mostly comes from personal files stored in Archives of the Odessa I. I. Mechnikov National University. A list of reviews on the works of the teaching staff of the department make it possible to draw conclusion about the importance of their academic activities. For the first time bibliographic materials published in the reference book are organized not by chronological principle, but by thematic principle of works of each member of the department staff. This principle of construction of the reference clearly represents the diversity of research activities of the department. This is confirmed in the second volume, which contains separate publications of scientists revealing the features of the style and direction of academic activities of the department.

Thus, the first steps of national biography studies were made in the $19^{\text {th }}$ century. Nowadays it is a full-fledged science that does not stand still, developing research methods

${ }_{6}$ Authors: author of introductory article and ideas V. P. Sa€nko; compilers: V. P. Pruzhina, T. S. Kara. 
and introducing new approaches as to presenting results. The results of biographical research, which is considered among the priority areas of research activities of the Scientific library of the Odessa I. I. Mechnikov National University, are briefly outlined in the article. Special attention is paid awarded to the publication of the series Development of Science at Odessa I. I. Mechnikov National University, which are prepared jointly with the faculties of the university. The life of a scientist and his academic activity, as well as University life and the formation of scientific areas, development of departments can be traced through the scientific biography. Examining of the environment of scientists and events in the country and Universities makes it possible to understand the actions, scientific preferences of each person, which proves that the process is interconnected.

\section{Список використаної літератури:}

1. Березівська Л. Д. Фаховий погляд на біографічну справу в Україні / Л. Д. Березівська // Українська біографістика. - 2018. - Вип. 16. - С. 298-304. - Рец. на кн.: Вітчизняні ресурси біографічної та біобібліографічної інформації: проблеми формування й використання : кол. монографія / В. І. Попик (кер. проекту), Н. І. Любовець, О. М. Яценко, С. М. Ляшко [та ін.] ; НАН України, Нац. б-ка України ім. В. І. Вернадського. Київ, 2016. 272 с.

2. Бугаєва О. Створення українського біографічного словника як етап відродження історичної пам'яті українського народу / О. Бугаєва // Українознавство. - 2003. - № 4 (9). - С. 360-363.

3. Ващенко В. В. Концепт «інтелектуальна біографія» та конструювавння «наукових біографій» в українській історіографії / В. В. Ващенко // Ейдос : альм. теорії та історії іст. науки. - 2009. - Вип. 4. C. 475-486.

4. Вклад физиков Одесского (Новороссийского) университета в развитие науки в Одессе, 1920-1933 / авт.сост.: М. А. Подрезова, В. В. Самодурова, Е. С. Мурашко ; науч. ред. В. А. Смынтына ; библиогр. ред. Е. В. Суровцева ; Одес. нац. ун-т им. И. И. Мечникова, Науч. б-ка. - Одесса : Астропринт, 2010. - 326 c. - (Развитие науки в Одесском (Новороссийском) университете / гл. ред. И. Н. Коваль ; вып. : Физика).

5. Готра О. Біографістика в контексті дослідження історії / О. Готра // Наук. вісн. Чернів. ун-ту. Серія: Історія. Політичні науки. Міжнародні відносини. - 2014. - Вип. 684-685. - С. 147-151.

6. Дьомін О. Б. Шукач слов'янських скарбів В. І. Григорович / О. Б. Дьомін, М. В. Алексєєнко ; авт. передм. І. М. Коваль ; наук. ред. В. О. Колесник ; відп. ред. М. О. Подрезова ; бібліогр. ред. Г. В. Великодна ; Одес. нац. ун-т ім. І. І. Мечникова, Наук. б-ка. - Одеса : ОНУ, 2015. - 482 с. - (Розвиток науки в Одеському національному університеті імені І. І. Мечникова / гол. ред. І. М. Коваль ; вип. : Славістика).

7. І Історія Академії наук України, 1918-1923 : документи і матеріали / упоряд.: В. Г. Шмельов, В. А. Кучмаренко, О. Г. Луговськой [та ін.]. - Київ : Наук. думка, 1993. - 570 с.

8. Історія кафедри української літератури Одеського національного університету імені I. I. Мечникова: персоналії і факти : у 2 т. / Одес. нац. ун-т ім. І. І. Мечникова, Наук. б-ка, Філол. ф-т ; авт. вступ. ст. та ідеї В. П. Саєнко ; наук. ред. Є. М. Черноіваненко ; відп. ред. М. О. Подрезова ; упоряд. та бібліогр. ред.: В. П. Пружина, Т. С. Кара. - Одеса : ОНУ, 2018. - Т. 1 : Біобібліографічний покажчик. - 606 с. ; Т. 2 : Антологія. - 618 с. - (Розвиток науки в Одеському національному університеті / гол. ред. І. М. Коваль ; вип. : Філологія).

9. Котлярова Т. В. Біографіка у вітчизняному науково-інформаційному просторі. Секція 5 Міжнародної наукової конференції «Бібліотека. Наука. Комунікація. Стратегічні завдання розвитку наукових бібліотек» (Київ, 3-5 жовтня 2017 р.) / Т. В. Котлярова // Українська біографістика. - 2018. - Вип. 16. C. $326-335$.

10. Ляшко С. М. Поняття «наукова біографія» у теорії та практиці історико-біографічних досліджень / С. М. Ляшко // Українська біографістика. - 2016. - Вип. 10. - С. 25-47.

11. Микулинский С. Р. В. И. Вернадский как историк науки / С. Р. Микулинский // Вернадский В. И. Труды по всеобщей истории науки / В. И. Вернадский. - 2-е изд. - М. : Наука, 1988. - С. 19-41.

12. Напередодні апогею: одеські роки філософа і психолога - професора Миколи Яковича Грота (18831886) / В. І. Подшивалкіна, І. В. Голубович, М. О. Подрезова, В. М. Хмарський, О. Є. Музичко ; упоряд.: В. В. Самодурова, О. С. Мурашко ; наук. ред. В. М. Хмарський ; відп. ред. М. О. Подрезова ; бібліогр. ред. Г. П. Бахчиванжи ; Одес. нац. ун-т ім. І. І. Мечникова, Наук. б-ка. - Одеса : ОНУ, 2016. - 454 с. - 
(Розвиток науки в Одеському національному університеті імені I. І. Мечникова / гол. ред. I. М. Коваль ; вип. : Психологія. Філософія).

13. Науки про Землю в Одеському (Новоросійському) університеті / Є. А. Черкез [та ін.] ; наук. ред.: М. О. Подрезова, О. Г. Топчієв ; бібліогр. ред. В. В. Самодурова ; Одес. нац. ун-т ім. І. І. Мечникова. Одеса : Астропринт, 2010. - 102 с. - (Розвиток науки в Одеському (Новоросійському) університеті / гол. ред. І. М. Коваль ; вип. : Географічні та геологічні науки).

14. Научное наследие Н. Н. Ланге в университетской библиотеке / В. И. Подшивалкина, Р. Н. Свинаренко, Е. В. Полевщикова ; авт.-сост.: М. В. Алексеенко [и др.] ; науч. ред. В. И. Подшивалкина ; отв. ред. М. А. Подрезова ; библиогр. ред. В. В. Самодурова ; Одес. нац. ун-т им. И. И. Мечникова. Одесса : Астропринт, 2010. - 350 с. - (Развитие науки в Одесском (Новороссийском) университете / гл. ред. И. Н. Коваль ; вып. : Психология).

15. Омельчук В. [Рецензія] / В. Омельчук // Бібл. вісн. - 1998. - № 6. - С. 42. - Рец. на кн.: Чишко В. С. Біографічна традиція та наукова біографія в історії і сучасності України / В. С. Чишко. Київ : БМТ, 1996. 239 c.

16. Попова Т. Н. Жизнеописание ученого-историка на перекрестке историографических традиций: Теория. Методология. Практика / Т. Н. Попова. - Одесса : Вид. Бондаренко М. А., 2017. - 455 с.

17. Самодурова В. В. Библиографы в контексте научного облика библиотеки ОНУ имени И. И. Мечникова: цели, задачи, новации / В. В. Самодурова // Вісн. Одес. нац. ун-ту. Серія: Бібліотекознавство, бібліографознавство, книгознавство. - 2015. - Т. 20, вип. 2 (14). - С. 152-164.

\section{References}

[1]. Berezivska L. D. Fakhovyi pohliad na biohrafichnu spravu v Ukraini [Professional view of biographical case in Ukraine]. Ukrainska biohrafistyka [Biographistica Ukrainica]. 2018, iss. 16, pp. 298-304. Retsenziia [Review]: Vitchyzniani resursy biohrafichnoi ta biobibliohrafichnoi informatsii: problemy formuvannia y vykorystannia. Kyiv, 2016. 272 p.

[2]. Buhaieva O. Stvorennia ukrainskoho biohrafichnoho slovnyka yak etap vidrodzhennia istorychnoi pamiati ukrainskoho narodu [Creation of the Ukrainian biographical dictionary as a stage of revival of historical memory of the Ukrainian people]. Ukrainoznavstvo [Ukrainian Studies]. 2003, no 4 (9), pp. 360-363.

[3]. Vashchenko V. V. Kontsept «intelektualna biohrafiia» ta konstruiuvavnnia «naukovykh biohrafii» v ukrainskii istoriohrafii [The concept of «intellectual biography» and construction of «scientific biographies» in Ukrainian historiography]. Eidos [Eidos]. 2009, Vol. 4, pp. 475-486.

[4]. Podrezova M. A., Samodurova V. V., Murashko Ye. S. Vklad fizikov Odesskogo (Novorossiyskogo) universiteta $v$ razvitie nauki v Odesse, 19250-1933 [Contribution of physicists of Odessa (Novorossiysk) University to the development of science in Odessa, 1920-1933]. Odessa, 2010, 326 p.

[5]. Hotra O. Biohrafistyka v konteksti doslidzhennia istorii [Biography in the context of history research]. Naukovyi visnyk Chernivetskoho universytetu. Seriia: Istoriia. Politychni nauky. Mizhnarodni vidnosyny [Scientific Bulletin of Chernivtsi University. Series: History. Political Science. International relations]. 2014, Vol. 684-685, pp. 147-151.

[6]. Domin O. B., Aleksieienko M. V. Shukach slov'ianskykh skarbiv V. I. Hryhorovych [The finder of Slavic treasures V. I. Grigorovich]. Odesa, 2015, 482 p.

[7]. Istoriia Akademii nauk Ukrainy, 1918-1923 : dokumenty i materialy [History of the Academy of Sciences of Ukraine, 1918-1923: documents and materials]. Kyiv, 1993, 570 p.

[8]. Istoriia kafedry ukrainskoi literatury Odeskoho natsionalnoho universytetu imeni I. I. Mechnykova: personalii i fakty : 2 t. [History of the Department of Ukrainian Literature of Odessa I. I. Mechnikov National University: personalities and facts]. Odesa, 2018.

[9]. Kotliarova T. V. Biohrafika u vitchyznianomu naukovo-informatsiinomu prostori. Cektsiia 5 Mizhnarodnoi naukovoi konferentsii «Biblioteka. Nauka. Komunikatsiia. Stratehichni zavdannia rozvytku naukovykh bibliotek» [Biography in the national scientific and information space. Section 5 of the International Scientific Conference. «Library. Science. Communication. Strategic tasks for the development of scientific libraries»]. Ukrainska biohrafistyka [Biographistica Ukrainica]. 2018, Vol. 16, pp. 326-335.

[10]. Liashko S. M. Poniattia «naukova biohrafiia» u teorii ta praktytsi istoryko-biohrafichnykh doslidzhen [The concept of «scientific biography» in the theory and practice of historical and biographical research]. Ukrainska biohrafistyka [Biographistica Ukrainica]. 2016, Vol. 10, pp. 25-47.

[11]. Mikulinskiy S. R. V. I. Vernadskiy kak istorik nauki [V. I. Vernadsky as a historian of science]. Vernadskiy V. I. Trudy po vseobshchey istorii nauki [V. I. Vernadsky. Proceedings on the general history of science]. Moskow, 1988, pp. 19-41. 
[12]. Naperedodni apoheiu: odeski roky filosofa i psykholoha-profesora Mykoly Yakovycha Hrota (1883-1886) [On the eve of the apogee: the Odessa years of the philosopher and psychologist-professor Nikolai Grot (1883-1886)] / Podshyvalkina V. I., Holubovych I. V., Podrezova M. O., Khmarskyi V. M., Muzychko O. Ye. Odesa, 2016, 454 p.

[13]. Nauky pro Zemliu v Odeskomu (Novorosiiskomu) universyteti [Earth Sciences at Odesa (Novorosiysk) University] / Cherkez Ye. A., Bilanchyn Ya. M., Krasiekha Ye. N. [et al.]. Odesa, 2010, 102 p.

[14]. Nauchnoe nasledie N. N. Lange v universitetskoy biblioteke [N. Lange's Scientific Heritage in the University Library] / V. I. Podshivalkina, R. N. Svinarenko, Ye. V. Polevshchikova [et al.]. Odessa, 2010, 350 p.

[15]. Omelchuk V. Retsenziia [Review]. Bibliotechnyi visnyk [Library herald]. 1998, № 6, pp. 42. Retsenziia [Review]: Chyshko V. S. Biohrafichna tradytsiia ta naukova biohrafiia v istorii i suchasnosti Ukrainy. Kyiv, 1996. 239 p.

[16]. Popova T. N. Zhizneopisanie uchenogo-istorika na perekrestke istoriograficheskikh traditsiy: Teoriya. Metodologiya. Praktika [Biography of the historian at the crossroads of historiographic traditions: Theory. Methodology. Practice]. Odessa, 2017, 455 p.

[17]. Samodurova V. V. Bibliografy v kontekste nauchnogo oblika biblioteki ONU imeni I. I. Mechnikova: tseli, zadachi, novatsii [Bibliographers in the context of the scientific appearance Library of Odessa I. I. Mechnikov National University: goals, objectives, innovations]. Visnyk Odeskoho natsionalnoho universytetu. Seriia: Bibliotekoznavstvo, bibliohrafoznavstvo, knyhoznavstvo [Odesa National University herald. Library studies. Bibliography studies. Bibliology]. 2015, t. 20, Vol. 2 (14), pp. 152-164.

Поступила 15.12.2020 г.

\section{Мурашко О. C.,}

завідувач інформаційно-бібліографічного відділу Наукової бібліотеки

Одеського національного університету імені I. I. Мечникова

вул. Преображенська, 24, м. Одеса, 65082, Україна

тел.: (048) 7221210

e-mail: bibik@onu.edu.ua

Самодурова В. В.,

головний бібліограф Наукової бібліотеки

Одеського національного університету імені I. I. Мечникова

вул. Преображенська, 24, м. Одеса, 65082, Україна

тел.: (048) 7221210

e-mail: bibik@onu.edu.ua

\section{РОЗВИТОК НАУКИ В ОДЕСЬКОМУ НАЦІОНАЛЬНОМУ УНІВЕРСИТЕТІ ІМЕНІ І. І. МЕЧНИКОВА КРІЗЬ ПРИЗМУ БІОГРАФІСТИКИ}

У статті розкривається роль особистості в історії класичного університета, розвиток вітчизняної біографістики в цілому, а також у Одеському національному університеті імені I. І. Мечникова, зокрема в університетській Науковій бібліотеці. У публікації коротко проаналізовано напрацювання в галузі біографістики. Наукова бібліотека ОНУ імені I. I. Мечникова протягом багаторічної практики, спираючись у своїй діяльності на рекомендації та приклади, почерпнуті з теорії й методики науки «біографістики», накопила багатий досвід у здійсненні біографічних досліджень, зробивши їх одним 3 пріоритетних напрямків своєї роботи. 
У статті вказані основні праці університетської бібліотеки в даному напрямку за останні роки: публікації у наукових журналах та збірниках, що написані у вигляді біографічних етюдів; енциклопедичні словники й довідники; персональні біобібліографічні покажчики та монографії. Увага акцентується на виданнях серії «Розвиток науки в Одеському національному університеті імені I. I. Мечникова», яка була заснована у 2010 р. Серія готується при тісному академічному співробітництві бібліотеки з кафедрами й цілими підрозділами університету. У статті зроблено огляд монографій, які вийшли в рамках цієі серии та присвячені як окремій особі, так і колективу вчених університету. В огляді вказано, як створюючи біографичні роботи, автори намагалися показати в них образи вчених різних спеціальностей, використовуючи при цьому певний контекст, різні композиційні варіанти біографічного матеріала й застосовуючи конкретний біографічний ключ. У кожній конкретній біографії подана характеристика оточення, в якому жила й працювала особа в рамках університетської корпорації. В работі над виданнями було задіяно багатий фактичний матеріал, зібраний в архівах університету, міста й області. Кожне 3 видань цієї серії має власну концепцію та структуру, яка була розроблена з урахуванням напрямків діяльності й специфіки поглядів ученого чи коллективу наукових співробітників, та відбиває їхній гідний внесок до науки Одеського університету.

Ключові слова: Одеський національний університет імені І. І. Мечникова, розвиток науки, біографістика, М. М. Ланге, М. Я. Грот, В. І. Григорович, фізичний факультет, геолого-географічний факультет, кафедра української літератури.

\section{Мурашко Е. С.,}

заведующая информационно-библиографическим отделом

Научной библиотеки

Одесского национального университета имени И. И. Мечникова

ул. Преображенская, 24, г. Одесса, 65082, Украина

тел.: (048) 7221210

e-mail: bibik@onu.edu.ua

\section{Самодурова В. В.,}

главный библиограф Научной библиотеки

Одесского национального университета имени И. И. Мечникова

ул. Преображенская, 24, г. Одесса, 65082, Украина

тел.: (048) 7221210

e-mail: bibik@onu.edu.ua

\section{РАЗВИТИЕ НАУКИ В ОДЕССКОМ НАЦИОНАЛЬНОМ УНИВЕРСИТЕТЕ ИМЕНИ И. И. МЕЧНИКОВА СКВОЗЬ ПРИЗМУ БИОГРАФИСТИКИ}

В статье раскрывается роль личности в истории классического университета, развитие отечественной биографистики в целом, а также в Одесском нацио- 
нальном университете имени И. И. Мечникова. В публикации речь идет о наработках университетской Научной библиотеки в области биографистики.

В статье перечислены основные труды университетской библиотеки в данном направлении за последние годы: энциклопедические словари и справочники; персональные биобиблиографические указатели и монографии. Внимание акцентируется на изданиях серии «Развитие науки в Одесском национальном университете имени И. И. Мечникова», основанной в 2010 г. В статье сделан обзор монографий, которые вышли в рамках названной серии и посвящены как отдельной личности, так и коллективу ученых университета.

Ключевые слова: Одесский национальный университет имени И. И. Мечникова, развитие науки, биографистика, Н. Н. Ланге, Н. Я. Грот, В. И. Григорович, физический факультет, геолого-географический факультет, кафедра украинской литературы. 